\title{
Pursuing the Chinese Dream

\author{
Institutional Changes of Chinese \\ Diplomacy under \\ President Xi Jinping
} \\ Zhao Kejin and \\ Gao Xin
}

\begin{abstract}
The past few years have witnessed a growing appeal, both from home and from abroad, that China should reform its diplomatic system and proactively embrace the historic transformation of its relationship with the world. Especially since the 18th National Congress of the Communist Party of China (CPC) in 2012, China's diplomatic system has undergone multiple changes within its basic framework. From the perspective of institutional dynamics, the system is shifting from emphasizing the role of serving the country's development to the role of serving the Chinese Dream, that is, the great renewal of the Chinese nation, putting more weight on top-level design, strategic coordination, and multidimensional diplomacy. These changes are determined by China's changing role in the world as well as the intrinsic demands of China's social development. In the future, it is expected that China's diplomatic system will maintain such a course of transformation, so as to reach a new
\end{abstract}

Zhao Kejin is Associate Professor at the Institute of Modern International Relations, Tsinghua University, PRC. Gao Xin is an MA candidate at the Department of International Relations, Tsinghua University.

(C) 2015 World Century Publishing Corporation and Shanghai Institutes for International Studies China Quarterly of International Strategic Studies, Vol. 1, No. 1, 35-57

DOI: $10.1142 / \mathrm{S} 2377740015500037$ 
balance between the existing international system and China's domestic governance system.

Keywords: Chinese diplomacy; diplomatic system; transformation; Chinese dream.

\section{Introduction}

Since the establishment of the People's Republic of China, diplomacy has been regarded as one of the most important frontlines of CPC undertakings. For example, Premier Zhou Enlai considered it as another version of the People's Liberation Army (PLA) formed by civil officials. ${ }^{1}$ In the past six decades, China's diplomatic missions have been increasing and diversifying, thanks to its growing status in and changing relations with the international community, which requires continuous reforms of China's diplomatic system and institutions. However, existing literature indicates a grave ignorance on this topic. ${ }^{2}$

Some very important developments since the 18th CPC National Congress in 2012 further bewilder world observers. The new Chinese leadership led by Xi Jinping has initiated a number of great adjustments to China's governance system including diplomacy, attracting intense attention from scholars both at home and abroad. ${ }^{3}$ For example, the Central Peripheral Diplomacy Work Conference and the Central Conference on Foreign Affairs were held successively in 2013 and 2014 to put forward a set of new ideas and to draft a series of clear regulations to strengthen and

${ }^{1}$ Foreign Ministry of People's Republic of China, Party Literature Research Office of CPC, ed., Zhou Enlai's Diplomacy Anthology (Peking: Party Literature Press, 1990), pp. 1-7.

${ }^{2}$ There are a few research works touching on this topic, see for example, Zhao Xiaochun, The Foreign Policy Decision-making System of the Developed Countries (Peking: Current Affairs Press, 2001); Feng Yujun, The Foreign Policy Decision-making Mechanism of Russia (Peking: Current Affairs Press, 2002); Zhang Lili, Diplomatic Decision (Peking: World Knowledge Press, 2007); Hao Yufan, Lin Su, eds., The Diplomatic Decision of China: Open and Multi-Social Elements Analysis (Peking: Social Sciences Academic Press, 2007); Zhao Kejin, The Transition and Position of Chinese Diplomatic System in Contemporary China (Peking: Current Affairs Press, 2013); Bai Yunzhen, The Changes and Transition of Chinese Diplomacy in Contemporary China (Peking: China Social Sciences Press, 2011), etc.

${ }^{3} \mathrm{Xi}$ Jinping, The Governance of China (Beijing: Foreign Language Press, 2014). 
oversee the execution and management of foreign affairs. Up till now, these regulations seem to have been carried out in a most collaborative and strict way in addressing various diplomatic issues and effectively serving China's national interests.

Some scholars hold that Chinese diplomacy has replaced its taoguang yanghui [keeping a low profile] strategy with a fenfa youwei [striving for achievement] strategy, ${ }^{4}$ which implies that China has entered the third stage of diplomacy after the first stage of "revolution diplomacy" during Mao Zedong's time and the second stage of "development diplomacy" in the Deng Xiaoping era. ${ }^{5}$ Yet other scholars believe that Chinese diplomacy features more continuity than novelty, so the general framework of Chinese diplomacy has not changed much. ${ }^{6}$ In fact, whether the stress is put on sustainability or reform and innovation of Chinese diplomacy, it would appear as only one side of China's foreign policy while missing the decision-making mechanism and the diplomatic system itself, thus lacking the tool to systematically observe and analyze the logic of Chinese diplomacy. In other words, the extant literature puts too much emphasis on one side or one segment of China's foreign policy but fails to depict the complete trajectory of the evolution of

China observers tend to focus on details of China's foreign policy while ignoring the evolving diplomatic system.
Chinese diplomacy. Therefore, in this article, the notion of diplomatic system is introduced to analyze the rationale of the development of Chinese diplomacy. The article will examine whether - and if so, how much - the system of Chinese diplomacy has changed since the 18th CPC National Congress, so as to help to understand the new developments in Chinese diplomacy.

${ }^{4}$ Yan Xuetong, "From Keeping a Low Profile to Striving for Achievement," Chinese Journal of International Politics, Vol. 7, No. 2, 2014, pp. 153-184.

${ }^{5}$ Zhao Kejin, "Constructive Leadership and China's Diplomatic Transformation," World Economic and Politics, No. 5, 2012, pp. 42-57.

${ }^{6}$ Zhang Qingmin, “Understanding China's Diplomacy since the 18th Party Congress," Foreign Affairs Review, No. 2, 2014, pp. 1-20. 


\section{The Chinese Diplomatic System: Diplomacy Led by the Party}

In the mainstream of diplomatic studies, the notion of diplomatic system has not received enough attention. Since the establishment of the Westphalian system, diplomacy has been the engine of international relations or the main system of international relations. ${ }^{7}$ When people think of the diplomatic system, they take it for granted that it should be a department set up by a sovereign state and one that is made up of professional diplomats, such as the foreign ministry, embassies in other countries and professional ambassadors. ${ }^{8}$ This understanding, in essence, is a form of what Max Weber called bureaucracy, which takes all diplomatic systems around the world as the same. This is more often than not a misperception. As an important component of a nation's governing regime, diplomacy is surely under the influence of the development of the society, the political system, as well as historical and cultural traditions of the country, leading to differences in the diplomatic objectives, the organization systems, and the operating systems. Thus, difference in diplomatic systems is also a key factor that affects the diplomatic relationships among countries.

In China, the diplomatic system is understood as the principles, norms, and specific behavior restrictions formed in the process of foreign policy making and its administration. Professor Li Hu proposed that the diplomatic system should be perceived through two dimensions, one of decision making, and the other of diplomatic management. ${ }^{9}$ Professor Jin Zhengkun of the Renmin University of China wrote that diplomatic systems are the systemic safeguard of diplomatic activities. Simply, put the term "diplomatic system" means, under certain historical situations, a diplomatic network that comprises diplomatic restrictions, thus ensuring that all the

${ }^{7}$ Raymond Cohen, "Put Diplomatic Studies on the Map," Diplomatic Studies Program Newsletter, May 4, 1998; Martin Wight and Hedley Bull, Systems of States (Leicester: Leicester University Press, 1977), p. 113.

${ }^{8}$ Donna Lee and David Hudson, "The Old and New Significance of Political Economy in Diplomacy," Review of International Studies, Vol. 30, No. 3, 2004, pp. 343-360; Kishan S. Rana, Foreign Ministries: Change and Reform, Paper presented at the International Studies Association, Montreal, 2004; G. R. Berridge, Diplomacy: Theory and Practice (London: Palgrave, 2002).

${ }^{9} \mathrm{Li} \mathrm{Hu}$, Hantang Waijiao Zhidushi [The History of the Diplomatic System in Han and Tang Dynasties] (Lanzhou: Lanzhou University Press, 1998), pp. 12-13. 
diplomatic activities can operate properly. Diplomatic norms, diplomatic rituals, and diplomatic organs are all fundamental components of the diplomatic system. ${ }^{10}$ Professor Chen Yan of Fudan University is an advocate of the notion that "diplomatic system means the rituals, treaties and regulations of how a nation handles its foreign affairs and its relations with the world. It also means the norms of the words and behaviors of government agencies and the officials when they are conducting diplomatic activities. In short, diplomatic history is a history of the practical rules surrounding diplomatic activity." As a result, in China, diplomatic systems can be defined as the rules regulating China's relationships with different countries and how China handles international affairs. In particular, it is the total of a series of rules as well as organizational and operational systems set out by the diplomatic organs led by the CPC.

By this working definition, China's diplomatic system under the sole leadership of the Party should be perceived through four dimensions:

1. Dangguan waijiao [Diplomacy overseen by the Party]. The Party is not only the paramount leader of the socialist cause in China, but it also presides over national diplomacy. The executive department of diplomacy has limited authority, with the overriding authority over the Ministry of Foreign Affairs retained by the CPC Central Committee, particularly the General Secretary of the Party. From the founding of the PRC to the beginning of the "reform and opening-up" era, diplomacy in China had been led directly by Chairman Mao Zedong and Premier Zhou Enlai. Premier Zhou said many times that "Our comrades in foreign affairs have limited authority, including me. There are occasions when I have to ask for instructions from Chairman Mao and the Party's Central Committee before reaching decisions." ${ }^{\prime 11}$ Since the adoption of the "reform and opening-up" policy, with the development of intraparty democracy, besides the CPC General Secretary, the premier, the other members of the politburo, and heads of related departments in charge of

${ }^{10}$ Jin Zhengkun, Waijiaoxue Gailun [An Introduction to Diplomatic Studies] (Peking: China Renmin University Press, 1999), pp. 59-61.

${ }^{11}$ Tang Longbin, "Mianhuai Zhouzongli de qingqie jiaohui” [Remembrance of the Kind Teachings of Premier Zhou], in Tian Zengpei and Wang Taiping, eds., Laowaijiaoguan Huiyi Zhouenlai [Zhou Enlai in the Memories of the Diplomats of the Old Generations] (Peking: World Knowledge Press, 1998), p. 110. 
foreign affairs are also involved in diplomatic affairs, but the top leader remains in possession of the highest command and direct power.

\section{Guikou guanli [Centralized management by specialized units]. Under} the unified leadership of the Party, diplomacy is actually managed by specialized units. All the foreign affairs-related institutions, people's organizations and social organizations are divided into individual units for specific purposes, ${ }^{12}$ with the members of the politburo and related department chiefs making up the Small Leading Group (SLG) in charge of foreign affairs. The centralized management by the SLG is usually realized by establishing a leadership team by the Party or a committee system. In order to enhance this managerial system, in March 1958, the SLG of Central Foreign Affairs was established by the Central Committee. A General Office of the Foreign Affairs SLG was also instituted as the administrative office and the main department of the State Council to manage foreign affairs. Despite multiple disruptions and hardships, the system of centralized management by the SLG has been institutionalized and sustained. Compared with other departments, the one in charge of foreign affairs is relatively closed and least susceptible to the influence of other departments.

3. Fengong fuze [Power division based on different responsibilities]. By the principle of zhongyang jueding, gefang quban [decisions by the central government are assigned to related departments to implement], a vice premier or a state councilor is chosen to be responsible for foreign affairs. Since the 1980s, as Vice Presidents, Ji Pengfei, Wu Xueqian, and Qian Qichen have all played this role consecutively, and so have state councilors Tang Jaixuan, Dai Bingguo, and Yang Jiechi. Besides the main channel of diplomacy from the government, other departments also have their own areas of responsibilities. For instance, the CPC

${ }^{12}$ Here, the meaning of the unit is similar to that of the system, or the "Tiaokuai relation." The system of centralized management by specialized units was established in 1953, so as to oppose decentralism and localism. The Party has divided the work of the government into commercial, politics and law, finance and trade, culture and education, and so forth, in order to strengthen its leadership of the government. This refers to the former Soviet Union's decision to set up corresponding working agencies in the Party like the government. The Communist Party of China basically adopted the same organization model as the Soviet Union. Refer to Soviet Union Marxism and Leninism Institute, The Construction of the Party in Socialist Countries (Peking: China Renmin University Press, 1985), pp. 305-306. 
International Department is in charge of party-to-party exchanges; the Foreign Affairs Bureau of the PLA General Staff Department is in charge of military-to-military exchanges; the Foreign Affairs Committee of the National People's Congress and the Foreign Affairs Committee of the Chinese People's Political Consultative Conference are in charge of improving parliamentary foreign relations. Through this division of power based on responsibilities, the implementation of foreign policies in China have been greatly improved and professionalized.

4. Waijiao wu xiaoshi [Foreign affairs is no small matter]. In China, diplomatic authority is highly centralized, in line with the saying that foreign affairs is no small matter. Mr. Xia Yan recalled Premier Zhou repeatedly stressing the importance of the diplomatic corps' limited authority, as well as the importance of not exceeding the limits of one's authority. To be discreet is the key of a diplomatic mission. In a foreign activity, even a single word that comes out wrong or a simple gesture that leads to misunderstanding could cause severe consequences. ${ }^{13}$ Wang Youping, a famous diplomat, has the same reflection in his later years that "diplomacy is just like war, which calls for great carefulness and discretion." ${ }^{14} \mathrm{Li}$ Zhaoxing, former Foreign Minister of China, further explained, "That foreign affairs is no small matter does not only mean that diplomacy usually concerns the fundamental interests of the people, but it also implies that we [diplomats] have very limited authority yet great responsibility. To be a diplomat means you have to be extremely serious and conscientious. Furthermore, diplomacy always has priorities, so when it comes to maximizing the preservation of our country's respect and rights, we should learn to focus on top priorities while leaving secondary concerns for later."15 All diplomats are told from Day One of their work that they should and must carry out the

${ }^{13}$ Xia Yan, "Yongyuan Nanwang de Jiaohui" [The Teaching I will Never Forget], in Pei Jianzhang, ed., Yanjiu Zhouenlai: Waijiao Sixiang he Shijian [Research on Zhou Enlai: Diplomatic Thoughts and Practice] (Peking: World Knowledge Press, 1998), p. 216.

${ }^{14}$ Fan Zhenbing, "Xiezai Zhouzongli Danchen Yibaizhounian de Rizili" [At the 100th Birthday of Premier Zhou], in Tian Zengpei, Wang Taiping, eds., Laowaijiaoguan Huiyi Zhouenlai [Zhou Enlai in the Memories of the Diplomats of the Old Generations] (Peking: World Knowledge Press, 1998), p. 216.

${ }^{15}$ Li Zhaoxing, "Waijiao Shiji Chudu Xinde" [The Reviews of Ten Accounts about Diplomacy], World View, No. 2, 2004. 
nation's will and never overuse their power delegated by laws and rules. In essence, the power of diplomats to handle foreign affairs comes from the nation. They carry great responsibilities, however little power is given to them, thus they should learn to exert great influence using limited power. People working at the Ministry of Foreign Affairs, therefore, are required to develop the habit of maintaining discipline and confidentiality. The principle that foreign affairs is no small matter and that their authority is limited have become basic axioms and also the major principle underlying the operation of China's diplomatic system.

China's diplomatic system has been developing on four dimensions, namely, the politburo system, especially its standing committee; the SLG system; power division based on responsibility system; as well as the system of departments with specific functions. The logic of this evolution is constructed on the basis of the responsibilities of the SLG, of departments with divided power and of their directors, finally extending into other areas in the CPC, the nation, and the society to form a complete system with overarching principles. This structure takes the shape of an extended umbrella with different levels, in which each and every level has clearly delineated superiors to make sure that the authority runs top down, so that the higher level has full command of the lower levels. ${ }^{16}$

On the whole, state authority reliant on the Party is the basic feature of China's diplomatic system. Since the 1980s, China's diplomatic principle has underscored the rational-legal authority of a sovereign nation, which stresses the democratization of the power structure in diplomacy as well as the bureaucratization of the operational mechanism. The CPC has gradually changed its leadership style over diplomacy from that of a revolutionary party to one that emphasizes law-based governance. The framework and the basis of a modern diplomatic system has been set up and strengthened. Nevertheless, China's diplomatic system still features "state authoritarianism reliant on the Party," with the Party and nation's centralized power directing and supervising diplomacy.

${ }^{16}$ This structure is an organizational form with a long history, utilized by the early Egyptians, Romans and Catholics. See Robert E. Lerner, Western Civilization, trans., Wang Juefei (Peking: China Youth Press, 2003), pp. 54-57, 179-181, 298-312. 


\section{Changes in the Diplomatic System After the 18th CPC Congress}

Since the 18th CPC National Congress, Xi Jinping has put forward the strategic idea of the "Chinese Dream," the concept of "Overall National Security," and the "One Belt and One Road" initiative, launching a range of adjustments and reforms of the diplomatic system as well as related mechanisms. Under the impetus of Xi Jinping's leadership, new improvements are witnessed in many fields: the unified leadership of the central government has been enhanced; the mechanisms and systems overseeing and handling foreign affairs have been reformed; and the coordination among local governments and departments regarding foreign affairs has been strengthened. To be more specific, there have been three major changes to China's diplomatic system since the 18th CPC National Congress: top-level design, strategic coordination and multi-dimensional diplomacy.

\section{Top-Level Design}

Since the adoption of the reform and opening-up policy, keeping a low profile has been at the core of China's foreign policy strategy. When facing major diplomatic issues, such as sensitive issues like island claims and maritime disputes or hotspot issues, China either adopted a policy of putting aside the dispute, or attempted to take the moral high ground by displaying an attitude of aloofness. Yet over the past years, China has put more and more emphasis on dealing with non-sovereign foreign-related issues using the technique of "mozhe shitou guohe" [crossing the river by feeling one's way], encouraging local governments and various departments to explore different ways of solving foreign-related issues. Thus, there is a tendency for diplomatic power to be decentralized, which can be seen from the following facts: First of all, besides the Ministry of Foreign Affairs, the National Development and Reform Commission, and other economic departments such as the Ministry of Finance, the Ministry of Commerce and the People's Bank of China, are all playing an increasing role in economic diplomacy. Secondly, the Ministry of Culture, the Ministry of Education and the Information Office of the State Council are also playing their part in cultural diplomacy, especially through the Confucius Institutes established abroad. Thirdly, the Headquarters of the PLA General Staff as well as other military departments are gradually gaining their own 
diplomatic power over arms control and nonproliferation. Starting from Mr. Tang Jiaxuan, state councilors in charge of diplomacy no longer hold a position as a member of the politburo or vice premier, unlike his predecessors Zhou Enlai, Chen Yi, Huang Hua, Wu Xueqian, and Qian Qichen.

The Ministry of

Foreign Affairs is

only one among

many that is

conducting China's

foreign affairs.
The Ministry of Foreign Affairs is only one among many that is conducting China's foreign affairs. This decline of the position of Ministry of Foreign Affairs is the most remarkable change regarding China's diplomatic bureaucracy since the 1990s.

The first systemic change of China's diplomatic system is the stress on "top-level design" and the rising importance of the politburo and its standing committee in designing China's overall foreign strategy. Xi Jinping has mentioned at different important conferences that the strategic planning of mid- and long-term foreign policy should be made as a top-level design, to "push forward the benign interaction and the combination of the top-level design and the grassroots-level exploration. ${ }^{\prime 17}$ In order to enhance the top-level design, especially when encountering the many challenges in China's peripheral diplomacy, China held the first ever Peripheral Diplomacy Work Conference in October 2013 to lay out the strategic aim, the basic policy, and the overall layout of China's peripheral diplomacy in the next five to ten years. It was attended by nearly all the politburo members, state councilors, Foreign Affairs SLG members, provincial CPC and government chiefs, heads of state-owned enterprises, senior military officials, ambassadors to major countries such as the United States, and Chinese representatives to major international organizations. A year later, in November 2014, another meeting called the Central Conference on Work Relating to Foreign Affairs, with even higher standards, was held to make plans for the overall layout of China's diplomacy, especially its diplomatic system. It was made clear at this conference that the role of the Party to lead diplomatic affairs should be strengthened, and the system and mechanism of foreign affairs should be reformed and perfected, while the principles of coordination of the foreign work relating to various fields, departments and locals should be enhanced, 
transforming the concept of top-down design into a feasible diplomatic norm.

The concept of top-level design of the system and mechanism of China's diplomacy brought up after the 18th CPC National Congress is explained by Yang Jiechi, State Councilor and Chief of the General Office of the Foreign Affairs SLG, in his article published in the Party journal, Qiushi: "The strategic plan of mid- and long-term work of foreign affairs is made from the perspective of top-level designing," reiterating a point stressed many times by $\mathrm{Xi}$ Jinping. ${ }^{18}$ As the State Councilor tasked with overseeing diplomacy, Yang underlines that when dealing with foreign affairs, all officials should "be integrated and coordinated to follow the top-level design under the unified command of the CPC." ${ }^{19}$ While the central and local governments, non-governmental organizations and all foreign affairs departments are performing their respective functions, they are also required to cooperate with each other in order to fulfill the harmonious coordination of foreign affairs. "It should be made sure that the leadership, decision making, management and the handling by the Central Committee of foreign affairs are implemented smoothly and successfully, so that the strategic intention of the Central Committee can be realized." ${ }^{20}$ It is evident that the top-level design has already replaced the previous thinking of "crossing the river by feeling one's way" and become the dominant thinking of China's diplomacy. This is the fundamental change of China's diplomatic institutions since the late 1970s, which facilitates the overall transformation of China's diplomacy.

\section{Strategic Coordination}

Because of the changing relationship between China and the world, especially when China surpassed Japan as the world's second largest economy in 2010, the scale and fields of China's foreign affairs have since been greatly expanded. Consequently, competition among different bureaucratic departments as a result of the decentralization of diplomatic power has

${ }^{18}$ Yang Jiechi, "Innovations in China's Diplomatic Theory and Practice under New Conditions," Xinhua news, August 16, 2013, http://news.xinhuanet.com/english/china/201308/16/c_132635189.htm.

${ }^{19}$ Ibid.

${ }^{20}$ Ibid. 
increased gradually, blurring the boundaries of power and interests. Various departments have begun to restrict their activities to narrowly selfdefined diplomatic spheres which directly concern their interests, while tending to ignore those duties that do not explicitly fall under their authority. This makes it hard to conduct foreign affairs in a united and coordinated manner. For example, the Ministry of Foreign Affairs has little information of foreign military sales or sensitive military items. ${ }^{21}$ Likewise, the central government is often not fully aware of international activities organized by local governments. ${ }^{22}$ Both the appointment of personnel and the cooperation among different organizations are becoming increasingly difficult because of the diversification of diplomatic power, the constant shifting of responsibility and accountability, and sometimes the unclear responsibilities of personnel. Even in issues such as maritime disputes, commercial and trade frictions, and global financial crisis, large-scale confusion has begun to arise due to tensions among bureaucratic interests. All these problems and phenomena are challenging the major principle that "foreign affairs is no small matter."

In order to coordinate various departmental efforts, in different fields and at different levels, the second major change of China's diplomatic system since the 18th CPC National Congress has been to introduce the idea of enhancing planning and coordination of foreign affairs, to ensure the centralized leadership over diplomacy. State Councilor Yang Jiechi stressed that since the 18th CPC National Congress, the Central Committee should coordinate both domestic and international efforts, paying close attention to planning and coordinating of foreign affairs. He put great emphasis on balancing internal and external affairs under the overall planning with wellorganized and coordinated implementation. He demanded that a unified and cooperative idea should be planted in every mind of the central and local governments, of the government and the public, and of every department handling foreign affairs. Only when each and every one of them

${ }^{21}$ Jonathan D. Pollack, "Structure and Process in the Chinese Military System," in Kenneth G. Lieberthal and David M. Lampton, eds., Bureaucracy, Politics, and DecisionMaking in Post-Mao China (Berkeley: University of California Press, 1992), p. 96.

${ }^{22}$ See Chen Zhimin, Ciguojia Zhengfu yu Duiwai Shiwu [Sub-national Government and International Affairs] (Beijing: Changzheng Press, 2001). 
plays their own part as required, can their work be joined together to better serve China's national interests.

Since 2013, to enhance the planning and coordination among different fields, the Central Committee has promoted the construction of coordinating mechanisms among departments relating to foreign affairs, as well as the coordination and cooperation among different departments. Several

The new Chinese

leadership takes

great efforts to

enhance top-level

designing and

coordination among

diplomacy-related

units. leading groups, such as the Central Small Leading Group for Comprehensively Deepening Reforms, the National Security Commission, and the Central Leading Group for Internet Security and Information were formed to enhance planning and coordination in specific fields. Likewise, in order to intensify coordination in maritime affairs, the National Ocean Council was set up, while the State Oceanic Administration was reorganized to institute the China Marine Surveillance department so as to integrate maritime enforcement powers and elevate the efficiency of related departments. ${ }^{23}$ All these newly formed departments, in essence, are coordinating departments under the leadership of either the CPC Central Committee or the State Council.

Furthermore, to ensure the implementation of foreign policies, the Central Committee also stresses the importance of acting by "political rules" and "political discipline," and "putting power into a cage" through the sweeping anti-corruption campaign, which has greatly enhanced the depth of supervision while reinforcing the importance of the system in diplomatic personnel's minds. Xi Jinping mentioned at the second plenary meeting of the 18th Central Commission for Discipline Inspection that, in order to prevent and overcome the problem of bureaucratic protectionism and departmentalism existing in some local governments, every effort must be taken to prevent the phenomenon of "when a policy comes from above, a countermeasure appears from below," or any intentional neglect of an

23“The State Council's Draft to Reorganize the State Oceanic Administration," http:// www.soa.gov.cn/xw/hyyw_90/201303/t20130311_24405.html. 
order or prohibition, or any discount or selective ways to implement the policy. ${ }^{24}$ In 2014, the Central Commission for Discipline Inspection announced that an assistant foreign minister was put under investigation for severely breaching these principles, a showcase of how the "political rules" are having a great impact on the behaviors of every department.

\section{Multi-Dimensional Diplomacy}

The political report of the 18th CPC National Congress has established the overall framework to unify the construction of economy, politics, culture, society and ecological civilization, all related to foreign affairs. Diplomacy is no longer merely a strictly political issue, but it has transcended the traditional idea that domestic issues and the outside world are separate. Statements about foreign affairs are expanding from international security and political issues to issues relating to the economy, society, culture and ecology. Domestic issues and international affairs are on the same chessboard with no clear limit in between. Thus, the level and depth of diplomacy have covered every dimension at home and abroad.

In the political arena, summit diplomacy is playing a remarkable role since the 18th CPC Congress. Traditional diplomacy by summit visits and meetings are designed by related departments and authorized by the Central Committee. After the 18th CPC Congress, Xi Jinping and Li Keqiang paid dozens of visits to Africa, Europe, Latin America, as well as the Oceanic and South Pacific Islands countries, appearing in a great many news reports and interviews and attending numerous foreign activities. All sorts of diplomatic resources of commerce, culture, military, local, general public and so forth are utilized in a most cooperative way, demonstrating a pattern designed by the Central Committee and involving people from all walks of life.

In the economic field, the report of the 18th CPC National Congress pointed out that China should adopt a more proactive and open strategy, "to coordinate the openness and cooperation on bilateral, multilateral and regional levels by accelerating the steps to implement the strategy of free trade zone and promoting the connections and communications with

24 " $\mathrm{X}$ Jinping: Never Allow the Phenomenon of "Where there is Policy, there is Countermeasure," Xinhua news, January 22, 2013, http://news.xinhuanet.com/politics/201301/22/c_114460744.htm. 
neighboring countries. ${ }^{25}$ On many international occasions, Chinese leaders have taken the initiative to set the agenda and bring up strategic proposals such as the "Asia-Pacific Free Trade Zone" and infrastructure investment, in an effort to provide public goods for the Asia-Pacific region. When setting the agenda, China not only embraces new topics like anti-corruption, antitax evasion and infrastructure investment, but also makes great efforts to promote these topics in the international society. Among the 100 cooperation proposals brought up during the APEC meeting, half were made by China. Moreover, China has actively concluded a number of cooperation agreements with other countries at the Brisbane G20 Summit, the East Asia Summit and the BRICS Leaders' Summit. With novel proposals like the BRICS Development Bank, Contingency Reserve Arrangement, Asian Infrastructure Investment Bank and the Silk Road Fund, China is playing an ever more important diplomatic role, indicating a new economic diplomacy "to make new Chinese achievements." For the sake of strengthening economic diplomacy, after the establishment of the Department of International Economic Affairs in 2012, the Ministry of Foreign Affairs established the International Economic and Financial Advisory Committee in December 2013 to reinforce economic diplomacy. ${ }^{26}$ The Ministry of Commerce also stresses the so-called "grand foreign aid," a coordinating mechanism among related departments in foreign aid.

In the social arena, after the 18th CPC National Congress, China has continued to emphasize and promote public diplomacy and cultural exchanges, preserve its lawful rights and interests abroad and, at the same time, develop friendly relationships among political parties and political organizations around the world through various exchange programs involving the National People's Congress, the Chinese People's Political Consultative Conference, as well as local governments and private associations. In October 2013, when attending the Peripheral Diplomacy Work Conference, $\mathrm{Xi}$ Jinping stressed the importance of building up a

${ }^{25} \mathrm{Hu}$ Jintao, "Firmly March on the Path of Socialism with Chinese Characteristics and Strive to Complete the Building of a Moderately Prosperous Society in all Respects Report to the Eighteenth National Congress of the Communist Party of China on November 8, 2012," People's Daily, November 18, 2012.

${ }^{26}$ Wang Yi, "Proactively Launching Economic Diplomacy with Chinese Plan and Chinese Voice," November 3, 2013, http://www.fmprc.gov.cn/mfa_chn/zyxw_602251/ t1105278.shtml. 
"community of a shared destiny" to enhance public diplomacy, people-topeople exchange, and cultural diplomacy. On May 15, 2014, Xi gave an important speech to mark the 60th anniversary of the Chinese Association for International Friendly Contact, in which he put great emphasis on promoting people's diplomacy, public diplomacy, and city diplomacy. ${ }^{27}$ As a result, the International Department of the CPC Central Committee, the Ministry of Foreign Affairs as well as the Chinese People's Association for Friendship with Foreign Countries are working together to promote public diplomacy and cultural exchanges centered on the "One Belt and One Road" strategic plan by allocating more social and human resources to diplomacy.

In the cultural arena, one of the important pillars of China's diplomacy is to elevate its cultural and soft power. Since the 18th CPC Congress, $\mathrm{Xi}$ Jinping has mentioned on many inspection tours that China should strengthen its cultural confidence and promote cultural exchanges. In his speech on August 19, 2013, Xi expressed the need for China to carry forward the national spirit with Chinese stories well told, China's voice further expressed, and patriotism and national morals vigorously strengthened. Foreign Minister Wang Yi also spoke a lot about carrying forward the traditional culture to provide public goods and Chinese wisdom for international affairs. Under the guidance of the Central Committee, the Ministry of Culture has led a coordinating mechanism of cultural diplomacy, with 16 ministries taking part, establishing a high-level consultation mechanism for cultural exchanges between China and the U.S., between China and Europe, and a series of other bilateral and multilateral dialogue mechanisms. In short, cultural diplomacy and people-to-people exchanges have become a very important pillar of China's diplomacy.

In the ecological arena, China stresses the concept to build a beautiful China, with the hope that the construction of ecological civilization can "make contributions to the eco-security of the whole world." Ecological diplomacy is gaining an ever more important place in the all-round diplomacy of China. During the Beijing APEC summit, China and the U.S. reached an agreement on greenhouse gas emissions mitigation, setting

${ }^{27} \mathrm{Xi}$ Jinping, "Speech on the 60th Anniversary of the China Association for International Friendly Contact," People's Daily, May 16, 2014. 
a very good example for the world to promote protection of the global environment. Early in 2015, Professor Chen Jining, then President of Tsinghua University, was nominated as Minister of Environmental Protection, which indicates the new leadership's determination toward environmental protection and management. Having obtained his doctorate in the United Kingdom, Chen Jining not only boasts professional knowledge about environmental protection, but also possesses great international communication skills, which will definitely be of great help for Chinese ecological diplomacy.

It is not difficult to see that since the 18th CPC National Congress, China's diplomatic framework has been upgraded from one based on traditional concepts and views to a multi-dimensional one. Diplomacy is no longer confined to the domain of foreign affairs, but it has become a multiplayer, multi-task undertaking for China - transformed from a mere governmental function under the control of the Ministry of Foreign Affairs

Diplomacy has

become a multi-player, multi-task undertaking for China. to one that includes the work of the Party, the government, the National People's Congress, the Chinese People's Political Consultative Conference, the PLA and so forth. Furthermore, it has transcended the political arena and extended to such fields as economy, society, culture, and ecological civilization.

\section{Causes of the Transformation}

What caused the transformation of China's diplomatic system? So far, most comments have focused on how China's diplomatic system should reform rather than analyzed how and why China's diplomatic institutions have been changed. This is in part because scholars can hardly observe China's diplomatic system from the inside, thus they usually have to address the issue from the perspective of China's foreign strategy and policies. In order to accurately explain why China's diplomatic system has been changed in this way since the 18th CPC National Congress, we attempt to identify the contributing factors from the statements of Chinese leaders and interviews of key personnel in China's diplomacy, and then analyze the nature of such systemic transformation. 


\section{Xi Jinping's Statements}

Enhancing foreign relations is an important part of Xi Jinping's mandate and power portfolio. To him, reforming the diplomatic system is not an isolated matter. It is not only an indispensable component of the development of socialism with Chinese characteristics, but also one of the keys to promote the national governance system and the modernization of governance capacity, so as to serve the grand strategic goal of realizing the Chinese Dream.

As for why the diplomatic system should be reformed, Xi Jinping stated that "Reform is the result of problems. When we are solving problems, the reform is also enhanced." 28 In the process of reform, "we should have a strong sense toward problems, for major problems can act as our guidance to grasp the key issues. By further pondering over different issues, we can find [out] resolutions to the overwhelming contradictions and problems

National

development and

security are two key

issues for China's

diplomacy. facing our development." ${ }^{29}$ Since the 18th CPC National Congress, national development and security are two "grave issues" for China's diplomacy. As Xi himself pointed out, "At present, our nation faces double pressure. Internationally, there are sovereignty issues, security issues and development interests to protect. Domestically, there is political security and social stability to preserve. All kinds of potential risks, predictable or not, are increasing." ${ }^{30}$ Therefore, Xi Jinping called for government leadership at all levels to "coordinate two designs, both of the domestic level and of the international level. Likewise, development and security should also be coordinated at the same time." ${ }^{31}$ Though he did not elaborate on the details of the two "grave issues," by stressing their importance, Xi made it clear that

${ }^{28} \mathrm{Xi}$ Jinping, "An Explanation on the Decision of the CССРC on Some Major Issues Concerning Comprehensively Deepening the Reform," Qiushi, No. 22, 2013; Xi Jinping, The Governance of China (Beijing: Foreign Language Press, 2014).

${ }^{29} \mathrm{Ibid}$.

30"Xi Jinping Attending Central Working Meeting on Foreign Affairs and Making Important Remarks," Xinhua news, November 29, 2014, http://news.xinhuanet.com/ttgg/ 2014-11/29/c_1113457723.htm.

${ }^{31}$ Ibid. 
diplomacy should not only serve the cause of modernization centered on economic construction as it did during the past three decades of reform and opening-up, but also serve the long-term stability of the nation. At the third plenary session of the 18th CPC National Congress, when Xi explained why the National Security Commission was established, he also mentioned that "our security system and mechanism cannot meet the needs of securing our nation, so we have to forge a powerful platform to plan and coordinate national security. It is high time a National Security Commission was established to unify the leadership of national security." ${ }^{32}$

Then, why does China need top-level design and strategic planning under the new leadership? Xi Jinping has answered this question as well. In his words: "to deepen all-round reform is a complex project, which calls for the efforts of more than just one or several departments, so a higher level of leading mechanism is in order." ${ }^{\prime 3}$ Meanwhile, he also noticed that "the obstacles of ideologies towards deepening the reform are not from outside the system but from the inside. ${ }^{34}$ Among the factors that hinder the reform from inside the system, it is Xi Jinping's belief that the biggest obstacle is the so-called "restrictions of a rigid way of thinking" and the "constraints of departmental interests." ${ }^{35}$ He emphasized that "we must break through the obstacles of ideology and the fences of entrenched interests." ${ }^{\prime 36}$ He believes that to reform means to have the courage and the willpower to readjust oneself, "by strengthening the relations, coordination and feasibility between different reforms," because "reform in any one field would affect the reforms in other fields, thus reforms in different fields should connect with each other. If the reform of different fields do not match each other, or even conflict to some extent, the all-round deepening of the reform will be hard to push forward. Even if it is imposed, the result will not be as satisfactory." ${ }^{\prime 37}$ As for diplomacy, Xi Jinping stressed at the Central Conference on Foreign Affairs that "the unified leadership of the Party must be reinforced; the

${ }^{32} \mathrm{Xi}$ Jinping, "An Explanation on the Decision of the CССPC on Some Major Issues Concerning Comprehensively Deepening the Reform," Qiushi, No. 22, 2013.

${ }^{33}$ Ibid.

${ }^{34}$ Ibid.

${ }^{35} \mathrm{Ibid}$.

${ }^{36}$ Ibid.

${ }^{37}$ Ibid. 
system and mechanism of foreign affairs must be reformed and perfected, while the planning and coordination of foreign affairs among different fields, departments and local governments must be enhanced. We should also expand the strategic investment, regulate the management of foreign affairs, and strengthen the construction of a strong leading team for foreign affairs." $^{38}$

From the statement of $\mathrm{Xi}$ Jinping about the reform of the diplomatic system, it can be seen that the effort to push forward the innovation of the diplomatic system and related mechanisms is not a result of some pre-set national strategy, but it is due to the many problems facing the realization of the Chinese Dream. It is also a part of constructing the national governance system and deepening the all-round reform. The core objective of the reform is to avoid "calamitous mistakes," while effectively coping with the two "grave issues" of development and security, maintaining the long-term safety of the nation. As Xi said, "China, as a vast country, should never make calamitous mistakes on fundamental issues. Once it does, there is no way to make amends. Our standpoint is that we should be brave and steady, exploring with boldness yet on careful deliberations." ${ }^{39}$

\section{The Diplomatic Roles of the State Councilor and the Foreign Minister}

State Councilor Yang Jiechi and Foreign Minister Wang Yi are both responsible for managing China's diplomatic system. Even though there are many departmental representatives involved in the Foreign Affairs SLG, when it comes to diplomatic issues, Yang Jiechi and Wang Yi are still playing a crucial role in assisting the CPC General Secretary. Thus, they are both key figures who can determine the changes to the diplomatic system, and important vehicles for conveying the rationale behind the changes of China's diplomatic

Yang Jiechi and Wang Yi play a key role in assisting $\mathrm{Xi}^{\prime} \mathrm{S}$ reform of China's diplomatic system. system.

38"Xi Jinping Attending Central Working Meeting on Foreign Affairs and Making Important Remarks," Xinhua news, November 29, 2014, http://news.xinhuanet.com/ttgg/ 2014-11/29/c_1113457723.htm.

${ }^{39} \mathrm{Xi}$ Jinping, "Deepening Reform and Open up, Building Beautiful Asia-Pacific," People's Daily, October 8, 2013. 
Since the 18th CPC National Congress, among the coordinating institutions directly under the Central Committee, two are playing an increasingly important role: one is the General Office of the SLG for Financial and Economic Affairs, with Liu $\mathrm{He}$ as its chief, and the other is the General Office of the Foreign Affairs SLG, headed by Yang Jiechi. To reinforce the unified management by the Central Committee of foreign affairs, the new leadership issued a set of Party and government directives, codes of behavior, and protocols regarding diplomats and government officials (both at the central and local levels) who are on overseas missions. These regulations have largely improved the status of the Foreign Affairs SLG, promoting its role of planning and coordinating related to diplomatic issues. To underscore the importance of enhanced coordination in diplomatic work, Yang Jiechi wrote in an article in the Party journal, Qiushi, that " $[\mathrm{t}] \mathrm{o}$ better coordinate the country's domestic and international agenda, the Party Central Committee attaches great importance to holistic management of foreign affairs. It calls for balanced considerations, overall planning, unified command and coordinated implementation. It requires the central and local governments, non-governmental organizations and all foreignrelated agencies to work together, each performing its respective functions.... Efforts should be made to ensure the smooth exercise of leadership by the Party Central Committee in decision making, management and specific handling of foreign-related affairs so as to realize its strategic intentions in diplomatic work." 40

Apart from paying foreign visits and participating in major international conferences, Wang Yi, representing the Chinese government, has put forward Chinese statements and proposals regarding international hotspot issues such as the Iranian nuclear issue, Syria's civil war, and the Ukraine crisis. He has received increasing media attention since the new leadership took office due to the adjustment of China's diplomatic strategy, aside from his personal strength. The status of the Ministry of Foreign Affairs has also been remarkably elevated as a result of the new diplomatic initiatives promoted by the new Chinese leadership.

${ }^{40}$ Yang Jiechi, "Innovations in China's Diplomatic Theory and Practice under New Conditions," Xinhua news, August 16, 2013, http://news.xinhuanet.com/english/china/201308/16/c_132635189.htm. 
Obviously, from Xi Jinping's statements about reform of the diplomatic system to the changing roles of Yang Jiechi and Wang Yi in China's diplomacy, the changes of China's diplomatic system can be attributed to two causes.

First, reform of China's diplomatic system is a result of the reform of the national governance system. Compared with the focus on economic development before the 18th CPC National Congress, China's diplomacy is now more inclined toward serving the Chinese Dream, with special focus on long-term stability and security. Development and security have become the two "grave issues" of China's diplomacy in the new era. Objectively, to avoid "calamitous mistakes" on fundamental issues requires the strengthening of unified leadership of the Party over diplomacy, the enhancement of the top-level design and the overall framework, and the incorporation of the diplomatic system reform into the general reform plan for the national governance system.

Secondly, the reform of the diplomatic system corresponds to the adjustment of China's foreign strategy. Before the 18th CPC National Congress, the guideline of China's foreign policy was to keep a low profile. In terms of great-power diplomacy, peripheral diplomacy, developing-country diplomacy, and multilateral diplomacy, China usually kept a very low profile with an aloof and flexible attitude, focusing more on maintaining a favorable external environment to facilitate China's modernization. After the Congress, however, China's foreign strategy has been reviewed and adapted to strive for greater achievements. Consensus has been reached in the new leadership that China in the new era should carry out great-power diplomacy with Chinese characteristics. A number of new initiatives and proposals have been unveiled, such as "new type of major-power relations," "balanced approach to economic interests and moral integrity," "Concept of Comprehensive National Security," and the "One Belt and One Road" strategy, all of which provide a higher demand and wider space for China's diplo-

"Seeking greater achievements" is replacing "keeping a low profile" as the underlying principle of China's diplomacy. macy, hence the necessity to reform China's diplomatic system into one that is integrated, open, transparent, disciplined and flexible. 


\section{Conclusion}

Since the 18th CPC National Congress, China's diplomacy has undergone great changes, which has triggered a round of international debate on China's diplomacy. Though it is still unclear whether the succession of China's foreign strategy will outweigh its changes, or the other way around, the reform of China's diplomatic system and institutions has not yet received adequate academic attention. The most important explanation lies in the fact that most China observers tend to explore China's diplomatic changes by examining its outer appearance and behavior rather than its internal dynamics, that is, institutional evolution.

In order to better explain the changes of China's diplomacy, we employ a systemic approach and find that China's diplomatic system has remained relatively stable since 1949, leaving a lot of legacies including diplomacy led by the Party, centralized management by specialized units, division of power based on responsibilities, and the principle that foreign affairs is no small matter. The new Chinese leadership has adopted such legacies as the basis of China's diplomacy, but has upgraded it from one under direct CPC leadership to one under indirect leadership by enhancing the national governance system as well as better planning and coordination. The systemic changes such as top-level design, planning and coordination, and multi-dimensional diplomacy imply that China's diplomatic system is heading toward one that features strong systemic characteristics. The future of China's diplomacy is expected to be more predictable and stable. Such changes are results of both the improvement of the national governance system and adjustment of China's foreign strategies to better fit its position on the world stage. 